\title{
MODIFIKASI PEMBELAJARAN DESAIN DASAR (NIRMANA) BAGI PROGRAM STUDI ANIMASI
}

\author{
Dyah Gayatri Puspitasari; James Darmawan \\ Visual Communication Design, School of Design, BINUS University \\ Jln. K.H. Syahdan No. 9, Palmerah, Jakarta Barat 11480 \\ dyah@binus.edu; adarmawan@binus.edu
}

\begin{abstract}
Nirmana (basic design) is a compulsory major for School of Design-Binus University student. Basically, nirmana related with perception of the sight sense (visual) through organizing sensation components which has related pattern or similarity so that becomes one unity that can be appreciated. Nirmana course prepares the student to have sharpness and sensitivity to visual elements that is the core of the disciplines from art and design, along with its branches. In practice, curriculum Nirmana may not necessarily be applied to all courses. On course of study animation, adjustment is needed, and even some modification to achieve the purpose of learning that is based on the vision course of study. This course study of animation has unique characteristics and slightly different content from other courses, where visual is not the only aspect, but inherent with motion, audio and storytelling. This research aims to discuss the formulation of learning strategies for Animation Courses so it can run optimally.
\end{abstract}

Keywords: nirmana, animation, visual perception, visual element, study programme

\begin{abstract}
ABSTRAK
Nirmana (desain dasar) merupakan mata kuliah wajib bagi mahasiswa School of Design - Binus University. Nirmana pada dasarnya berkaitan dengan persepsi indera penglihatan (visual) melalui pengorganisasian komponen-komponen sensasi yang memiliki hubungan, pola, ataupun kemiripan sehingga menjadi kesatuan yang dapat diapresiasi. Mata kuliah Nirmana mempersiapkan mahasiswa agar memiliki ketajaman dan kepekaan terhadap unsur-unsur visual yang merupakan inti dari disiplin seni dan desain beserta cabangcabangnya. Dalam pelaksanaannya, kurikulum Nirmana tidak serta merta bisa terapkan pada semua program studi. Pada Program Studi Animasi, dibutuhkan penyesuaian-penyesuaian dan bahkan modifikasi untuk dapat mencapai tujuan pembelajaran yang sesuai dengan visi Program Studi. Program Studi Animasi memiliki karakteristik yang unik dan muatan yang sedikit berbeda dengan program studi lain, di mana visual tidak menjadi satu-satunya aspek, tetapi inheren dengan motion (gerak), audio dan storytelling. Penelitian ini bertujuan mendiskusikan formulasi strategi pembelajaran bagi Program Studi Animasi agar dapat berjalan lebih optimal.
\end{abstract}

Kata kunci: nirmana, animasi, persepsi visual, elemen visual, program studi 


\section{PENDAHULUAN}

Dalam kurikulum pembelajaran dunia pendidikan dasar desain Perguruan Tinggi Indonesia, mata kuliah Nirmana senantiasa dipetakan sebagai salah satu mata kuliah dasar di semester satu. Walau bisa saja upaya ini dapat dipandang sebagai implikasi dari adanya standardisasi, atau sebuah template kreativitas di dalam desain itu sendiri (Indrajaya, 2013), namun Nirmana dimaknai sebagai wadah yang mengawali upaya memberi pemahaman akan dasar-dasar desain.

Nirmana berkaitan dengan pengorganisasian atau penyusunan elemen-elemen visual seperti titik, garis, warna, ruang dan tekstur menjadi satu kesatuan yang harmonis.Nirmana dapat juga diartikan sebagai hasil imajinasi dalam rangkaian bentuk dwimatra dan (atau) trimatra yang harus mempunyai nilai keindahan. Nirmana disebut juga ilmu tata rupa yang biasa dipelajari oleh mahasiswa seni, kriya, desain dan yang terkait persepsi visual. Nirmana pada dasarnya mempelajari mengenai elemen-elemen senirupa yang meliputi empat elemen dasar utama yakni titik, garis, bidang, dan pejal.

Adapun 'titik' adalah bentuk terkecil yang hampir tanpa dimensi. Titik yang paling umum berbentuk bundaran sederhana, mampat, tak bersudut dan tanpa arah. Sedangkan 'garis' adalah suatu hasil goresan nyata dan secara imajiner merupakan batas limit suatu benda, ruang, rangkaian masa dan warna (Lester, 2006). Elemen dasar utama yang ketiga adalah 'bidang', dapat dipahami sebagai suatu bentuk pipih tanpa ketebalan, mempunyai dimensi pajang, lebar dan luas, mempunyai kedudukan, arah dan dibatasi oleh garis. Elemen dasar utama yang terakhir adalah 'pejal', yakni suatu bentuk bidang yang mempunyai dimensi ketebalan dan kedalaman (Lester, 2006).

Nirmana tidak berorientasi pada fungsi tetapi lebih kepada persepsi, yaitu bagaimana penyusunan elemen-elemen visual lebih sebagai ekspresi atas keindahan, bukan dorongan fungsional. Secara naluriah, manusia bisa merasakan keteraturan dari pola-pola visual yang sebenarnya acak dalam suatu komposisi. Misalnya ketika sedang mengamati awan, seringkali kita merasa mirip dengan bentuk-bentuk tertentu (pragnanz). Hal ini secara teoretis dapat dijelaskan dengan menggunakan prinsip-prinsip Gestalt maupun pendekatan kognitif. Gestalt menguraikan persepsi terhadap objek sebagai struktur (Lester, 2006), sementara pendekatan kognitif lebih melihat persepsi sebagai operasi mental. Mata kuliah Nirmana (Desain Dasar) merupakan mata kuliah wajib bagi mahasiswa seni dan desain. Meskipun diterima secara umum sebagai bentuk pembelajaran dasar senirupa, pada pelaksanaannya terjadi penyesuaian-penyesuaian dengan semakin beragamnya sub-disiplin desain dan seni. Salah satunya, yakni: Animasi.

Mata kuliah Nirmana pada Program Studi Animasi - Binus University diadopsi (baca: dipinjam) dari kurikulum yang dibuat untuk Program Studi New Media. Meskipun sama-sama berada dalam payung School of Design, tetapi sebagai dua disiplin dengan fokus kajian yang berbeda, maka penyeragaman kurikulum dan metode pembelajaran adalah mustahil. Pada animasi, selain visual melekat pula aspek motion (gerak), depth (kedalaman), audio dan storytelling, sehingga pembelajaran Nirmana pada Program Studi Animasi butuh penyesuaian dan strategi tersendiri agar mata kuliah ini dapat berjalan efektif dan optimal. Meskipun memberi penegasan pada beberapa aspek, Nirmana pada Program Studi Animasi tidak ditujukan untuk mengecilkan Nirmana pada disiplin lain, tetapi justru dimaksudkan untuk memperkaya dan memperluas aplikasi Nirmana untuk membangun fondasi dalam apresiasi karya visual. 


\section{METODE}

Penelitian ini merupakan penelitian tindakan kelas (classroom action research). Penelitian tindakan kelas ini berkaitan dengan upaya untuk mengubah kondisi riil saat ini ke arah kondisi yang diharapkan (improvement oriented). Dalam kajian ini, penelitian tindakan dilakukan untuk meningkatkan pemahaman materi mata kuliah Nirmana oleh mahasiswa Program Studi Animasi Binus University melalui pendekatan kontekstual. Peningkatan pada aspek keterampilan (termasuk ketrampilan mengapresiasi) berimbas juga pada peningkatan hasil belajar seni mahasiswa Program Studi Animasi. Peningkatan keterampilan seni mahasiswa diharapkan terjadi setelah dosen melakukan penyusunan rancangan model pembelajaran Nirmana dan melaksanakannya dengan menggunakan pendekatan kontekstual. Peningkatan tersebut dilihat dari hasil penilaian proses dan hasil karya seni yang dilakukan mahasiswa selama kegiatan belajar-mengahar berlangsung.

Penelitian tindakan kelas ini dimaksudkan untuk pemecahan masalah dengan ruang lingkup yang tidak terlalu luas berkaitan dengan hal-hal yang dihadapi dosen sendiri dalam kegiatan pembelajaran yang dilaksanakan di kelas. Ciri-ciri penelitian tindakan kelas sebagaimana yang diungkapkan Maryunis (2003) adalah: "diawali dengan adanya hal-hal yang tidak beres dalam praktek pendidikan, dan dapat juga diawali dengan adanya ide atau gagasan untuk melakukan perbaikan atau perubahan”. Berkaitan dengan penelitian ini, perubahan diarahkan pada strategi atau pendekatan pembelajaran yang peneliti lakukan sendiri pada kegiatan pembelajaran di kelas.

Adapun tujuan dilakukannya penelitian ini untuk mengkaji permasalahan yang menyangkut prilaku seseorang atau kelompok tertentu disatu lokasi tertentu dengan penelaahan yang teliti terhadap suatu perlakuan dan mengkaji sampai sejauh mana dampak perlakuan itu dan menghilangkan aspekaspek negatif dari pelaku yang sedang diteliti. Santoso (2001) menjelaskan penelitian tindakan kelas merupakan "suatu proses dimana dosen dan mahasiswa menginginkan terjadinya perbaikan, meningkatkan, dan perubahan pembelajaran dapat tercapai secara optimal”.

\section{HASIL DAN PEMBAHASAN}

Penelitian tindakan ini dilakukan berdasarkan model spiral Kemmis dan Mc. Taggart (1988) yang terdiri dari empat langkah. Langkah pertama, mengembangkan rencana tindakan yang akan dilakukan untuk memperbaiki situasi yang terjadi. Langkah kedua, melakukan tindakan untuk menjelaskan rencana. Langkah ketiga, mengamati dampak dari situasi yang disampaikan dalam konteks kejadian. Langkah keempat, merefleksikan dampak tersebut sebagai dasar perencanaan dan seterusnya hingga terbentuk sebuah siklus.

Berdasarkan langkah diatas, maka penelitian ini dilaksanakan yang diawali dengan orientasi, perencanaan, tindakan, observasi dan refleksi yang disebut dengan siklus I, selanjutnya siklus II ditentukan oleh hasil refelksi siklus I dengan memperbaiki perencanaan awal dan pemecahan masalah berdasarkan masalah yang ada pada siklus I, demikian seterusnya sampai terjadimya peningkatan kemampuan belajar yang dapat dilihat dari peningkatan hasil belajar yang tercermin pada penilaian hasil belajar mahasiswa.

\section{Perencanaan dan Pelaksanaan Tindakan}

Pembahasan pada tingkat perencanaan dimulai dari penemuan masalah sampai akhirnya ditentukan rencana tindakan kelas. Secara terperinci langkah-langkah pada tahapan ini dimulai dari hal penemuan masalah di lapangan. Adapun masalah utama di lapangan, yakni dalam perkuliahan 
Nirmana pada Program studi Animasi Binus University adalah kesenjangan antara orientasi dosen sebagai pengelola kelas dalam menentukan materi perkuliahan, serta kesenjangan kemampuan mahasiswa dalam menerima materi perkuliahan Nirmana. Juga terdapat jarak antara materi ajar yang berbasis New Media dengan kebutuhan mahasiswa dan program studi, sehingga belum terjadi kesesuaian antara materi ajar dengan hasil perkuliahan.

Pemilihan masalah selanjutnya berdasarkan pemahaman akan karakteristik Program Studi Animasi, yang memiliki kebutuhan berbeda dari New Media atau Desain Komunikasi Visual secara umum. Dalam tahap ini semakin tampak bahwa dua aspek utama yang perlu mendapat perhatian lebih adalah aspek kedalaman (depth), dan aspek ilusi gerak (motion). Perumusan hipotesis tindakan berdasarkan masalah yang telah dirumuskan, hingga tindakan-tindakan yang akan dilakukan adalah mengamati karya-karya mahasiswa yang telah memuat isu-isu tertsebut di atas, kemudian dibuat pengembangannya di masa mendatang. Langkah tindakan berikutnya adalah, menambahkan materi tersebut di ats ke dalam materi ajar secara proporsional tanpa mengurangi substansi mata kuliah Nirmana. Setelah kedua langkah tindakan ini, maka dapat dilakukan sosialisasi baik kepada tim dosen dan mahasiswa, mengenai pentingnya penambahan aspek animasi ke dalam mata kuliah Nirmana pada Program Studi Animasi Binus University.

Tahap setelah perencanaan, adalah dilakukannya tahap pelaksanaan tindakan. Pada pelaksanaan tindakan di kelas didasarkan rencana perlakuan yang dituangkan pada materi ajar yang telah disusun. Oleh karena itu, pelaksanaan tindakan diupayakan tidak menyimpang dari rencana perlakuan. Pada saat tindakan berlangsung, peneliti dibantu kolaborator melaksanakan observasi dengan menggunakan instrumen yang telah disiapkan. Pengamatan dilakukan dengan cermat dari awal hingga akhir pembelajaran berlangsung. Selain mencatat data yang ada, peneliti dan kolaborator juga memberikan catatan atas berbagai masalah yang dijumpai dengan menggunakan catatan lapangan.

Hasil observasi kelas, rekaman data, maupun catatan lapangan dan data lainnya dianalisis bersama-sama dengan praktisi (kolaborator) yang terlibat dalam penelitian ini. Refleksi dilakukan pada akhir tindakan setiap siklus. Hasil analisis digunakan untuk merencanakan tindakan pada siklus berikutnya. Tindakan yang telah berhasil dapat dilanjutkan pada pembelajaran berikutnya, sedangkan tindakan yang belum berhasil diubah dan diperbaiki.

\section{Perkuliahan Nirmana}

Mata kuliah Nirmana yang diajarkan pada mahasiswa Animasi tahun ajaran 2012/2013 masih menggunakan materi ajar (CO/OR) yang sepenuhnya mengadopsi materi ajar New Media, sehingga orientasi pengajaran masih "terbatas" pada aspek visual non-gerak. Belum ada pengkayaan materi khusus terkait (prinsip) animasi seperti misalnya exaggeration atau follow through. Kalaupun ada materi tersebut masih mendompleng secara sporadis dan belum dibahas secara khusus. Padahal dua prinsip tersebut sangat krusial dalam animasi.

Tim dosen pengajar mata kuliah Nirmana di Program Animasi secara komposisi masih belum ideal. Terkadang bahkan terjadi kesenjangan yang sangat mencolok di mana sebagian dosen sangat menguasai materi konseptual, sementara sebagian yang lain cenderung mengabaikan gagasan-gagasan yang sifatnya abstrak dan menonjolkan kemampuan teknis di bidang animasi. Hal ini salah satunya diakibatkan karena materi ajar (CO/OR) yang ada saat ini tidak mengakomodasi kebutuhan Program Studi Animasi dan hanya meminjam dari mata kuliah yang sama di Program Studi yang lebih dulu berdiri.

Kemampuan mahasiswa dalam menangkap materi Nirmana juga sangat beragam dan tak luput dari kesenjangan. Sehingga hal ini menambah kompleksitas pembelajaran Nirmana di Program Studi Animasi. Bagi kebanyakan mahasiswa, Nirmana hanya seperti trial and error dalam rangkaian usaha untuk memahami ekspresi visual dan bukan berdasarkan pemahaman akademik tertentu untuk 
memahami dan menghasilkan suatu karya. Akibatnya, banyak karya mahasiswa yang dangkal dan menganggap Nirmana sebagai mata kuliah yang bisa disepelekan.

\section{Perkuliahan di Program Studi Animasi}

Program Studi Animasi Binus University merupakan sedikit di antara institusi pendidikan yang mempelajari animasi. Selain Binus University, studi animasi juga terdapat di IKJ (Institut Kesenian Jakarta) dan Amikom Yogjakarta. Ketiganya menempatkan animasi sebagai bagian dari pendidikan desain atau senirupa.

Meskipun berada dalam lingkungan desain dan senirupa (School of Design), tetapi Program Studi Animasi Binus sangat menonjol secara teknis. Hal ini pula yang menjadi orientasi sebagian besar mahasiswa. Di mana mereka menganggap hanya mata kuliah teknis saja yang akan berguna bagi mereka, sementara mata kuliah dasar dan konseptual seperti Nirmana seringkali diremehkan. Tetapi tentu hal ini tidak sepenuhnya mewakili kondisi kelas, sebab sebagian yang lain masih ada yang merasa bahwa mata kuliah ini mengasyikkan.

Seperti disinggung sebelumnya. Program Studi Animasi memiliki karakteristik dan kebutuhan yang berbeda dari New Media atau Desain Komunikasi Visual secara umum. Dari hasil wawancara yang dilakukan pada sejumlah dosen dan mahasiswa diperoleh beberapa aspek utama yang patut diperhatikan dalam mata kuliah Nirmana untuk Program Studi Animasi Binus University, yakni pada aspek kedalaman (depth), dan aspek ilusi gerak (motion). Depth atau kedalaman suatu objek visual dibentuk melalui serangkaian persepsi yang dapat dijelaskan salah satunya oleh prinsip Gestalt. Dalam animasi, kedalaman suatu scene sangat bergantung pada pengorganisian element-element visual seperti foreground, midground, dan background (Poulin, 2011). Prinsip tentang depth sebenarnya sudah terpenuhi dalam materi ajar sebelumnya, tetapi yang dimaksud masih sebatas bagaimana menghadirkan volume. Sementara pendekatan dalam animasi lebih pada membangun scenery yang naratif.

Ilusi gerak (motion) tidak dimaksudkan semata pada gerak organik yang bersifat mimesis atau tiruan dari gerakan unsur-unsur alam sebagaimana yang biasa ditemukan dalam animasi organik.Tetapi justru lebih dimaksudkan pada pengorganisasian elemen-elemen visual yang "diam” menjadi seolah-olah "bergerak” (Poulin, 2011).

\section{Elemen Nirmana dan Prinsip Gestalt}

Analisis dilakukan melalui matriks untuk memantau perkembangan karya mahasiswa mata kuliah Nirmana sesuai dengan data dan temuan yang didapatkan. Pada elemen Nirmana analisis mengacu pada tiga kelompok komposisi, yakni: komposisi dengan dominasi pada elemen titik, komposisi dengan dominasi pada elemen garis, dan komposisi dengan dominasi pada elemen bidang. Sebagai tahap selanjutnya, tiap seri dari kelompok komposisi elemen tersebut akan direlasikan dengan dua aspek permasalahan utama, yakni aspek depth, dan aspek motion. Pada telisik beberapa karya komposisi Nirmana mahasiswa yang mermiliki keterhubungan dengan kajian ini, akan tersingkap bagaimana upaya pengkomposisian beberapa elemen dasar (titik, garis, bidang), dalam menghadirkan muatan aspek depth dan motion.

Pada prinsip Gestalt, analisis akan mengacu pada enam kelompok prinsip utama, yakni proximity, similarity, closure, continuity, common fate, dan pragnanz. Selanjutnya tiap kelompok prinsip utama tersebut akan direlasikan pula dengan dua aspek permasalahan utama, yakni aspek depth dan aspek motion. Pada telisik beberapa karya komposisi Nirmana mahasiswa yang memiliki muatan keterhubungan dengan kajian ini, akan tersingkap bagaimana relasi antar prinsip Gestalt yang diimplementasikan dalam mengupayakan penghadiran kedua aspek tersebut. Pelbagai kecenderungan 
kerja otak dalam membentuk persepsi visual akan suatu asosiasi maupun organisasi, mampu diurai dalam telisik yang mengacu pada tiap prinsip utama dalam teori Gestalt.

Tabel 1 Elemen Nirmana dalam Depth dan Motion

Elemen Nirmana

Depth atau kedalaman suatu objek visual dibentuk melalui serangkaian persepsi yang dapat dijelaskan salah satunya oleh prinsip Gestalt. Dalam animasi, kedalaman suatu scene sangat bergantung pada pengorganisian elemen-elemen visual seperti foreground, midground, dan background.

Pada Tabel 1 di atas, dapat dilihat suatu kedalaman yang dihasilkan dari karya komposisi titik, dalam rangkai tata letak yang membentuk suatu fluiditas, dengan satu titik pusat sebagai lokus pijar. Arah titik menuntun pandangan pada lingkar patahan-patahan garis yang tersusun secara gradual mengikuti arah putar dari lokus sebagai energi pusat. Keniscayaan pusat perhatian pandang terarah pada irama patahan garis yang kian tampil sebagai pengimbang daya lokus. Patahan-patahan sedemikian tertuntun oleh gradual susunan titik, dan membentuk suatu area yang menangkap erat unsur dimensi, yakni dimensi kedalaman. Pusat energi tidak lagi pada lokus, melalui fluktuasi gradual garis, energi lebih diarahkan pada dimensi kedalaman yang terbentuk oleh area ayun putarnya. 
Sedangkan depth pada karya komposisi garis, dapat dilihat sebagai bentukan atau dampak samping permainan elemen-elemen garis tebal (bold) yang tersusun secara vertikal-paralel. Diawali dengan permainan susun silang antar hitam (positive) dan putih (negative) garis, pada paralel garis ilusi lengkung yang mendiagonal. Permainan susun silang ini membentuk kesan pergeseran yang akhirnya menghadirkan suatu area yang memuat dimensi kedalaman. Walhasil, rentang kedua ilusi garis lengkung tersebut mampu mewujud sebagai focal point pada karya komposisi garis ini. Hal ini diperkuat dengan posisinya yang men-diagonal.

Depth pada karya komposisi bidang, dapat dilihat sebagai hasil bentukan permainan tata letak bidang segitiga bertekstur garis yang disusun secara gradual. Komposisi ini bertendensi pada upaya memusat ke suatu lokus khayal yang menggejala pada pola asimetris. Kelengangan area pusat tampak diupayakan kembali kesan kedalamannya dengan menghadirkan rancang dalam bentuk bidang bertekstur titik. Bentukan ini memberi klimaks pada ujung lingkarnya, yang berkelindan dengan bentukan bidang negatif sebagai space counter. Pertemuan ujung lingkar dari permainan bidang positif dan negatif ini, tampak menjadi pusat energi yang mampu menarik arah serta daya pandang pada spirit dimensi kedalaman yang direpresentasikan oleh tatanan irama gradual bidang-bidang segitiga tersebut. Akhirnya dapat dilihat, bahwa tatanan bidang-bidang segi tiga yang tersusun sedemikian mampu menghadirkan depth pada keseluruhan karya komposisi ini.

Ilusi gerak (motion) tidak dimaksudkan semata pada gerak organik yang bersifat mimesis atau tiruan dari gerakan unsur-unsur alam sebagaimana yang biasa ditemukan dalam animasi organik. Tetapi justru lebih dimaksudkan pada pengorganisasian elemen-elemen visual yang "diam” menjadi seolah-olah "bergerak". Gerak disini lebih sebagai suatu ilusi yang tertangkap secara optikal dari daya persepsi inderawi semata.

Pada Tabel 1 di atas, dapat dilihat bentukan-bentukan aspek motion yang dihasilkan dari komposisi titik yang dibentang dalam formasi tata letak yang berbeda dalam empat macam arah. Tata letak ini meniscayakan energi gerak pada daya pandang yang tertuntun secara berirama mengikuti deret komposisi pada tiap arahnya. Permainan dengan skala yang meng-gradual, juga tampak turut serta berperan untuk membentuk daya gerak (motion) pada persepsi visual. Secara optikal daya pandang dari skala kecil atau halus, yang mengarah pada skala yang lebih besar atau nyata, berpotensi menghasilkan suatu ilusi gerak pada komposisi itu. Hal ini diperkuat dengan tata letak paralel yang diposisikan sedemikian hingga menghasilkan bentuk ujung (akhir) yang tidak sama panjang, hingga aspek dinamis tampil kuat di sana. Walhasil aspek dinamis tersebut semakin menambah ujar ikhtiar keseluruhan karya komposisi titik ini pada aspek ilusi gerak (motion) yang mampu tertangkap dan terasa oleh persepsi inderawi.

Lain halnya dengan ilusi gerak yang terbentuk pada karya komposisi garis. Dapat dilihat, bahwasanya peletakan elemen secara keseluruhan pada arah yang mendiagonal, sangat berpotensi menuturkan daya gerak sebagai keutamaannya. Ditambah pula dengan tata letak yang sangat mengedepankan daya pilin antar garis organik, menjadikan komposisi ini sarat akan keriuhan ilusi gerak yang memang diupayakan menjadi jati diri dari karya komposisi garis ini. Dengan demikian kompleksitas dari bentukan gerak pilin antar elemen garis pun semakin mampu menghadirkan emphasis motion dari keseluruhan karya ini.

Sedangkan ilusi gerak pada karya komposisi bidang, tampak sebagai hasil bentukan akan permainan tata letak yang memanfaatkan unsure space. Tampak pada karya tersebut, bahwasanya kontras juga diupayakan sebagai penguat yang memendam daya eksplosif pada elemen-elemen bidang. Latar hitam pada komposisi tersebut ini mampu tampil sebagai daya eksplosif, daya utama yang mematahkan dan menyebar elemen-elemen bidang. Adapun tampilan bentuk elemen-elemen sebagai bidang geometris acak yang berkesan tajam, mampu menghasilkan kesan bahwa bidangbidang tersebut sebagai hasil patahan akan suatu daya eksplosif yang menjadikannya sebagai bentukan fragmen-fragmen retak, hancur, tersebar, dan berdesakan. Dengan demikian, keseluruhan karya ini 
meniscayakan motion yang bermuasal dari lokus eksplosif yang menyudut, sebagai gugahan kehancuran sekaligus gerak fragmen-fragmen retakan yang menyebar dan berdesakan merapat ke arah sudut oposisi diagonalnya.

Tabel 2 Proximity, Similarity, dalam Depth dan Motion

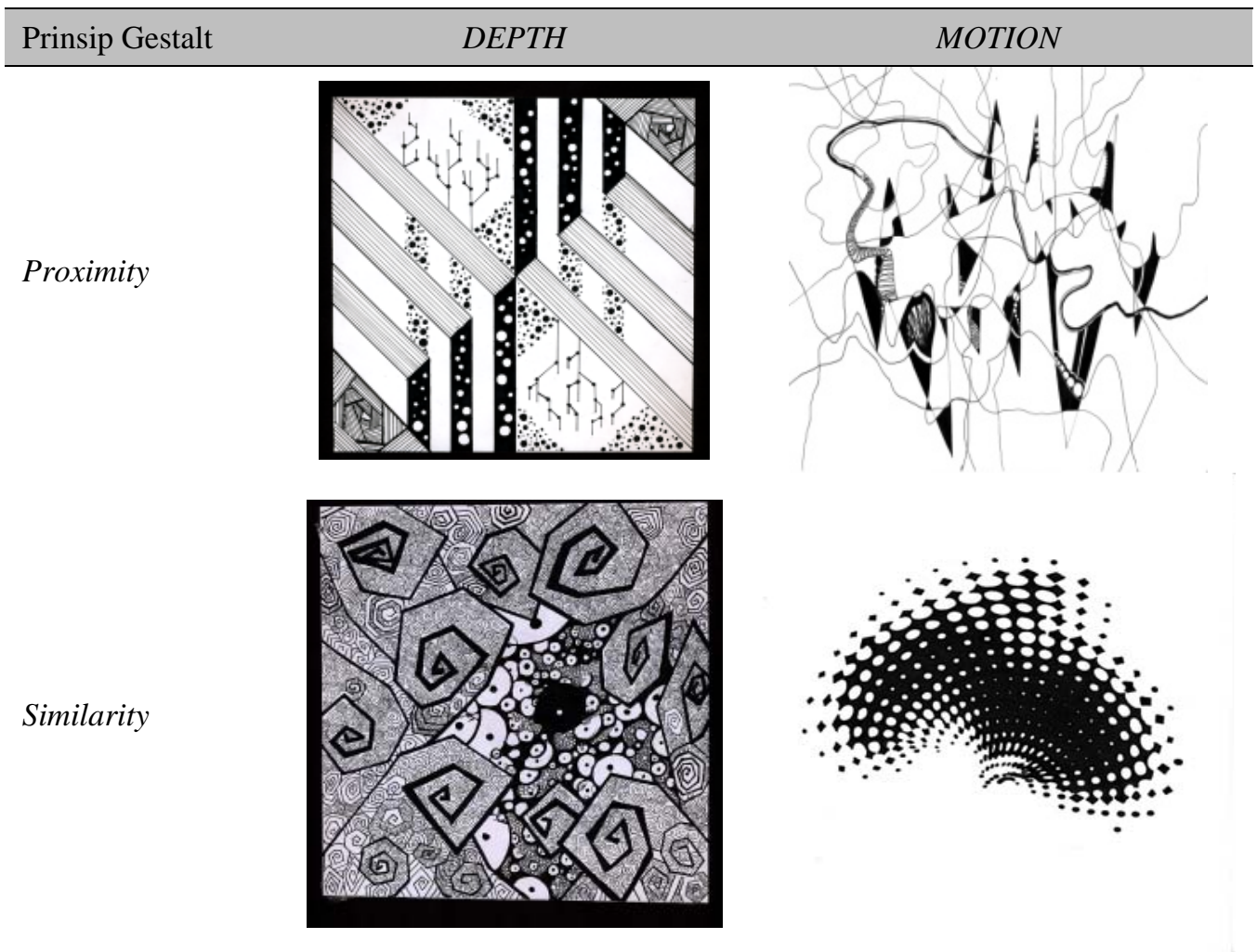

Proximity dalam teori Gestalt adalah prinsip yang menjelaskan bagaimana persepsi visual mampu terbentuk dari kemampuan otak yang cenderung memberikan perhatian kepada objek-objek yang berdekatan (kedekatan posisi) dibandingkan yang tidak (Lester, 2006). Pada Tabel 2 di atas, dapat dilihat bagaimana dua buah karya mampu mengimplementasikan proximity dalam kreativitas rancang komposisinya.

Karya komposisi pertama, sebagai karya yang memuat aspek depth, mendayakan proximity melalui bentuk-bentuk bidang persegi panjang yang disusun diagonal-paralel, juga melalui bentukbentuk bidang negatif persegi panjang yang tersusun vertikal-paralel. Penghadiran kedua komposisi ini ditempatkan pada konsep tata letak saling silang (counter) pada area yang berseberangan. Secara keseluruhan pertemuan tata letak elemen-elemen diagonal dan vertikal tersebut mampu menghadirkan dimensi kedalaman (depth) berdasarkan suatu prinsip kedekatan posisi, yakni proximity.

Karya komposisi kedua, sebagai karya yang memuat aspek motion, mendayakan proximity melalui bentuk-bentuk fluiditas garis-garis organis yang saling berdekatan membentuk kesan ilusi gerak pada daya pandang. Ilusi gerak ini tampak ingin mengimbangi bentukan statis dari elemenelemen bidang segitiga yang disusun menyebar dan bertaut pada garis-garis organis tersebut. Selain itu ditampilkan pula dua garis organis berdekatan yang lebih tebal (bold), yang mampu memperkuat kesan gerak dan kebertautan seluruhan elemen dalam komposisi karya tersebut. Dengan demikian karya tersebut mampu tampil sebagai karya yang menghadirkan aspek motion berdasarkan proximity. 
Similarity dalam teori Gestalt adalah prinsip yang menjelaskan bagaimana persepsi visual mampu terbentuk dari kemampuan otak yang cenderung mengorganisasi dengan melakukan pengelompokan pada objek-objek yang memiliki kesamaan bentuk (Lester, 2006). Pada Tabel 2 di atas, dapat dilihat bagaimana dua buah karya mampu mengimplementasikan similarity dalam kreativitas rancang komposisinya.

Karya komposisi pertama, sebagai karya yang memuat aspek depth, mendayakan similarity melalui kesamaan bentuk sulur bersegi yang ditata mengelilingi bidang karya. Kesamaan bentuk berupa sulur lingkar halus tampak mengisi penuh ruang antara sulur bersegi, hingga membentuk tekstur. Untuk mempertegas aspek kedalaman, ditampilkan komposisi gradual dari elemen-elemen lingkar yang memiliki kesamaan bentuk, dengan variasi dot di pusatnya. Secara keseluruhan karya komposisi ini mampu tampil sebagai karya yang menghadirkan aspek depth berdasarkan prinsip kesamaan bentuk (similarity).

Karya komposisi kedua, sebagai karya yang memuat aspek motion, mendayakan similarity melalui tatanan kesamaan bentuk dari elemen dot gradual, yang disusun menjadi pola setengah lingkar yang dinamis. Tampak permainan saling silang antar dot positif dan negatif menghasilkan sensasi dinamis otptikal yang kaya akan aspek ilusi gerak. Walhasil karya komposisi ini mampu tampil sebagai karya yang menghadirkan aspek motion berdasarkan prinsip kesamaan bentuk (similarity).

Tabel 3 Closure, Continuity, dalam Depth dan Motion

Prinsip Gestalt

Closure dalam teori Gestalt adalah prinsip yang menjelaskan bagaimana persepsi visual mampu terbentuk dari kemampuan otak yang cenderung berasosiasi dengan mencipta ruang imajiner tertentu bahkan ketika disusun dari objek yang tidak lengkap (Lester, 2006). Pada Tabel 3, dapat dilihat bagaimana dua buah karya mampu mengimplementasikan closure dalam kreativitas rancang komposisinya.

Karya komposisi pertama, sebagai karya yang memuat aspek depth, mendayakan closure melalui asosiasi ruang imajiner kedalaman yang dibentuk dari garis bold yang tersusun kuat memijar, dengan tatanan lingkar dari perpaduan garis light maupun bold yang menghubungkan garis-garis pijar utama tersebut seolah menjadi satu kesatuan bentuk yang mengkerucut ke dalam. Siasat gradual 
menuju lokus khayal semakin memperkuat arahan pada aspek depth. Dengan kecenderungan kerja otak yang memberi asosiasi pada indera tatap, maka daya pandang akan menangkap sekaligus membentuk ruang imajiner kedalaman tersebut pada karya ini. Hingga secara keseluruhan karya ini mampu mengedepankan aspek depth berdasarkan suatu prinsip penutupan bentuk (closure).

Karya komposisi kedua, sebagai karya yang memuat aspek motion, mendayakan closure melalui asosiasi ruang imajiner gerak dari tatanan serangkaian persegi panjang yang tampil dalam bentuk kontur putih (negatif). Sebelum tiba pada asosiasi ilusi gerak pada rangkaian ini, prinsip penutupan bentuk terjadi pada bentukan persegi panjang itu sendiri, yakni pada saat kontur putih melintas pada bidang latar putih, hingga secara kasat mata garis itu menghilang dan bentukan persegi panjang menjadi tidak utuh. Namun dengan closure, persepsi visual mampu memahaminya sebagai suatu bentuk persegi panjang yang utuh. Setelah tahap ini, dilanjutkan pada asosiasi ruang imajiner gerak yang tertangkap pada tata rangkai beberapa persegi panjang. Susunan tumpang tindih pada beberapa persegi panjang, memperkuat asosiasi akan kesatuan rangkai gerak daya lingkar yang searah jarum jam. Walhasil, dengan closure, rangkai persegi panjang pada karya ini terasosiasi memiliki daya gerak lingkar yang mampu menembus batas bidang karya.

Continuity dalam teori Gestalt adalah prinsip yang menjelaskan bagaimana persepsi visual mampu terbentuk dari kemampuan otak yang cenderung mengurutkan objek-objek pada kesinambungan pola atau alur tertentu (Lester, 2006). Pada Tabel 3 di atas, dapat dilihat bagaimana dua buah karya mampu mengimplementasikan continuity dalam kreativitas rancang komposisinya.

Karya komposisi pertama, sebagai karya yang memuat aspek depth, mendayakan continuity melalui kesinambungan elemen-elemen garis yang membentuk pola arsir silang pada dua buah bidang segi tiga sama sisi. Dengan kesinambungan pola tersebut, kedua segi tiga sama sisi tersebut mampu menghadirkan sebuah persepsi akan suatu dimensi kedalaman yang meruang. Hingga asal mula bentuk segi tiga flat, mampu tampil sebagai bentang jaring segi tiga yang terpilin meruang, sebagai ruang yang memuat aspek depth. Sedangkan kesinambungan garis-garis tegas yang memijar dari kedua belah arah, sanggup mengimbangi titik berat pada kedua segitiga sama sisi, tergaris menjadi bagian dari silang jaring kedua segitiga tersebut, dan membentuk kesan meruang ringan serta sentuhan keharmonisan bagi keseluruhan komposisi. Walhasil dapat dilihat, bahwa melalui continuity, keseluruhan karya komposisi ini mampu mengoptimalkan kesinambungan pola dan alur tertentu guna menghadirkan aspek utamanya, yakni aspek depth.

Karya komposisi kedua, sebagai karya yang memuat aspek motion, mendayakan continuity melalui kesinambungan elemen-elemen garis yang membentuk pola anyam dengan tekstur garis yang berbeda arah. Varian dari arah tekstur garis ini sangat berpotensi menghadirkan aspek motion pada komposisi karya. Emphasis kesinambungan pola anyam yang mememnuhi ruang bidang karya, serta merta mampu meniscayakan kekuatan daya persepsi visual dalam menyerap dan menangkap suatu ilusi akan gerak. Hingga secara keseluruhan, kesinambungan pola anyam dengan varian tekstur sedemikian seolah mampu menghantar daya pandang pada ritme ilusi gerak repetitif tanpa henti. Dengan demikian karya komposisi ini mampu tampil sebagai karya yang menghadirkan aspek motion berdasarkan prinsip kesinambungan pola (continuity). 


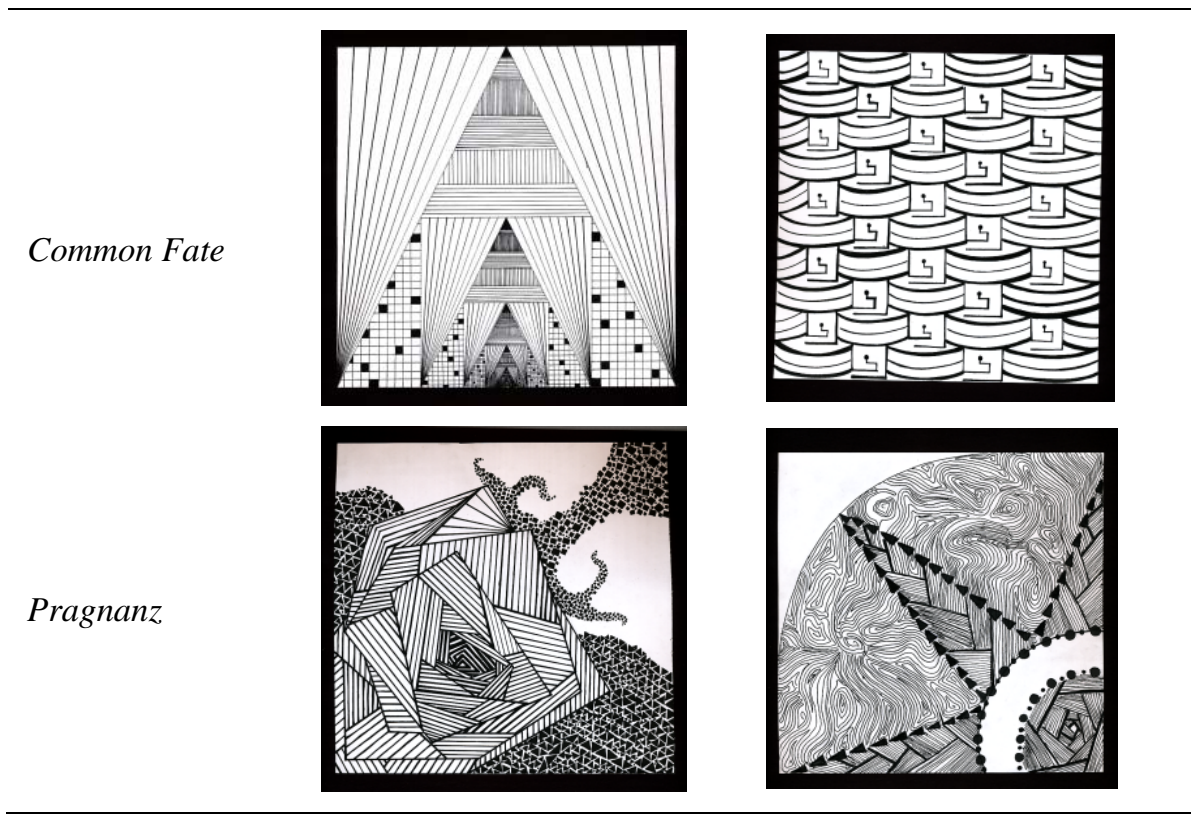

Common fate dalam teori Gestalt adalah prinsip yang menjelaskan bagaimana persepsi visual mampu terbentuk dari kemampuan otak yang cenderung mengorganisasi objek-objek yang memiliki arah gerak yang sama dibandingkan yang tidak (Lester, 2006). Pada Tabel 4 di atas, dapat dilihat bagaimana dua buah karya mampu mengimplementasikan common fate dalam kreativitas rancang komposisinya.

Karya komposisi pertama, sebagai karya yang memuat aspek depth, mendayakan common fate melalui arah gerak yang sama dari beberapa elemen garis dan bidang yang tersusun gradual. Dominasi arah gerak bidang segitiga dengan tekstur garis tegas, sangat mendominir arah tuntun persepsi visual pada suatu kedalaman ruang yang terasa begitu lugas dan tajam, bahkan pada ruang yang terdalam sekalipun. Aksentualitas dot berupa square hitam tampak pula terorganisasi dengan arah gerak yang sama, menuntun arah pandang pada suatu kedalaman. Sehingga secara keseluruan dapat segera kuat tertangkap, bahwa karya komposisi ini mampu mendayakan common fate dalam soatu proses kreatif menghadirkan aspek depth yang demikian lugas.

Karya komposisi kedua, sebagai karya yang memuat aspek motion, mendayakan common fate melalui arah gerak yang sama dari elemen garis lengkung, yang tersusun dalam pola repetisi. Pada karya ini persepsi visual akan ilusi gerak semakin mampu terbentuk oleh daya bentang pola anyam yang mendominasi keseluruhan bidang karya. Arah pandang akan langsung tercerap dan tertuju pada bentukan lengkung repetitif yang meniscayakan intensitas daya tangkap pandang pada unsur totalitas ritme dari ilusi gerak yang merata pada seluruh permukaan bidang. Aksentualitas dalam bentuk garis lengkung tebal (bold) pada bebrapa garis lengkung, mampu mempertegas kejelasan (clarity) arah gerak dari komposisi anyam tersebut. Memandang karya ini, akan jelas tampak bahwa pengorganisasian elemen-elemen dengan arah gerak yang sama mampu membentuk persepsi visual yang kuat akan aspek motion.

Pragnanz dalam teori Gestalt adalah prinsip yang menjelaskan bagaimana persepsi visual mampu terbentuk dari kemampuan otak yang cenderung mengasosiasikan bentuk atau keteraturan tertentu (yang telah dikenal) dari pola-pola visual yang sebenarnya acak (Lester, 2006). Pada Tabel 4 di atas, dapat dilihat bagaimana dua buah karya mampu mengimplementasikan pragnanz dalam kreativitas rancang komposisinya. 
Karya komposisi pertama, sebagai karya yang memuat aspek depth, mendayakan pragnanz melalui tatanan beberapa elemen bidang yang bertekstur garis, sebagai asosiasi bentuk sekuntum bunga mawar dengan kelopak mahkotanya yang bertumpuk. Bentuk bidang geometris disusun tumpang tindih, acak, dan gradual, mengarah pada lokus yang memberi intensitas daya pandang akan dimensi kedalaman. Kompleksitas dari barik yang dibentuk dengan guratan garis arsir yang berbeda arah, tampak hadir sebagai ritme yang coba menjemput arah pandang, untuk dapat dihantarkan menuju arah perjalanan kedalaman lokus. Asosiasi dan keteraturan semakin kuat terbentuk dengan penghadiran tekstur latar diagonal yang membentuk latar pekat sebagai asosiasi permukaan rerumputan, serta tangkai bunga. Dengan demikian komposisi karya ini nyata sebagai karya yang mengimplementasikan pragnanz melalui olah bentuk bidang dan kompleksitas barik yang memuat aspek depth, hingga terbentuk persepsi visual yang mampu menhgadirkan asosiasi akan bentukan sekuntum bunga mawar.

Karya komposisi kedua, sebagai karya yang memuat aspek motion, mendayakan pragnanz melalui ekspos tekstur, dan rangkaian dots. Ekspos tekstur latar dengan bentuk kontur melingkar pada karya ini meniscayakan suatu asosiasi pada keteraturan bentuk yang telah dikenal, yakni bola dunia. Dapat dicermati, bahwa aspek ilusi gerak disematkan pada permukaan 'bola dunia' ini melalui ekspos pola acak testur yang terdiri dari kumpulan garis organis yang menghadirkan fluiditas sebagai asosiasi gerak atmosfir bumi. Di samping itu bentukan fluiditas ini menghadirkan pula dimensi 'bulat' pada bidang lingkaran tersebut. Hingga pada bidang spasial lingkaran ini, mampu kuat terbentuk persepsi visual akan bentuk 'bola dunia'. Sedangkan ekspos rangakain dots dengan bentuk garis zig-zag, menghadirkan bentukan asosiasi terhadap objek bintang. Daya pandang tertuntun oleh ilusi gerak dari rantai dots dalam bentuk segitiga kecil, yang secara repetitif menuntun arah pandang pada ritme kontur. Pada akhir gerak ritme kontur, serta merta akan terbentuk persepsi visual yang mengasosiasikan bidang tersebut sebagai 'bintang'.

Lain halnya dengan asosiasi yang terbentuk dari ritme gerak barik yang disematkan pada lingkar spasial kecil yang menyudut. Pada bidang ini, secara cukup detail digarap dengan suatu kompleksitas barik yang mengandaikan dinamika akan arah gurat. Dengan ritme sedemikian, meniscayakan penghadiran asosiasi akan suatu bentuk kelopak mawar. Walhasil dapat semakin dilihat bahwa secara keseluruhan, karya ini mampu mengimplementasikan pragnanz - melalui ekspos tekstur, rangkaian dots - hingga memposisikan muatan aspek motion sebagai pemegang peran kunci terbentuknya persepsi visual akan bentukan bola dunia, bintang, dan mawar.

\section{SIMPULAN}

Perubahan kurikulum merupakan sesuatu yang wajar dalam rangka meningkatkan kualitas pendidikan di Binus University. Sejak tahun ajaran 2012 Animasi berdiri sendiri sebagai program studi.Sehingga perlu dilakukan berbagai penyesuaian termasuk mata kuliah fundamental seperti Nirmana. Mata kuliah yang diadopsi dari induk School of Design ini harus disesuaikan menurut karakteristik, kebutuhan dan visi Animasi sebagai program studi baru.

Nirmana sebagai mata kuliah wajib dalam disiplin desain dan kesenirupaan, sangat relevan untuk meningkatkan daya apresiasi dan kreativitas mahasiswa Program Studi Animasi.Selain karena pada dasarnya animasi berkaitan erat dengan persepsi visual, Nirmana juga memberikan pijakan bagaimana seharusnya berpikir kreatif bagi calon-calon desainer, seniman, dan termasuk animator.Tetapi meskipun demikian, berbagai modifikasi tetap diperlukan terutama berkaitan dengan aspek-aspek yang menjadi inti Program Studi Animasi seperti gerak dan penceritaan agar lebih relevan dengan bidang yang relatif masih sangat muda di Indonesia ini. 
Penelitian Tindakan Kelas (Classroom Action Research) yang dilakukan di Program Studi Animasi Binus University ini menghasilkan beberapa poin penting diantaranya adalah perombakan materi ajar (CO/OR) dan pengayaan dosen pengajar mata kuliah tersebut agar mata kuliah Nirmana sejalan dengan visi Program Studi dan Binus sebagai induk organisasi. Upaya perbaikan perkuliahan tidak bisa dilaksanakan sekali-dua kali, tetapi harus konsisten dan berorientasi pada peningkatan mutu pendidikan di Program Studi Animasi Binus University. Selain perbaikan pada kurikulum secara makro, perbaikan juga harus dilakukan melalui detail-detail perkuliahan yang menuntut partisipasi peneliti, dosen, administrator, dan tentu saja mahasiswa yang dirumuskan dalam kebijakan-kebijakan yang suportif.

\section{DAFTAR PUSTAKA}

Indrajaya, F. (2013). Uebermensch sebagai Radikalisasi Filsuf Alamiah (Krisis Pelampauan Diri dalam Dunia Pendidikan Desain). Jurnal Humaniora: Language, People, Art, and Communication Studies. 4(2): 1166-1175.

Kemmis, S., McTaggart, R. (1988). The action research planner. Victoria: Deakin University.

Lester, P. M. (2006). Visual Communication: Images with Message. Toronto: Thomson Wadsworth Publishing.

Maryunis, A. (2003). Usage of information mapping to stimulate learning process and outcomes of strategized teachings of mathematics. Education Journal. 26 (2).

Poulin, R. (2011). The Language of Graphic Design: An Illustrated Handbook for Understanding Fundamental Design Principles. New York: Rockport Publishers.

Santoso, S. (2000). Problematik Pendidikan dan Cara Pemecahannya. Jakarta: Kreasi Pena Gading. 